\title{
In vitro growth of Cattleya nobilior Rchb. f.: culture media, sealing systems and irradiance ${ }^{1}$
}

\author{
Kaliana Gottschalk de Freitas², José Carlos Sorgato², \\ Jackeline Schultz Soares ${ }^{2}$, Luan Marlon Ribeiro ${ }^{2}$
}

\section{ABSTRACT}

Some factors may influence the in vitro culture of native orchids, especially the culture medium, sealing system and light condition. This study aimed to evaluate the addition of banana pulp and peel in the formulation of culture media, sealing system and irradiance, in the in vitro growth of Cattleya nobilior Rchb. f. A completely randomized design was used in a factorial scheme with five culture media [Murashige \& Skoog supplemented or not with banana pulp or peel (100 or $\left.200 \mathrm{~g} \mathrm{~L}^{-1}\right)$ ], two light conditions [3,000 K LED lamps $\left(43 \mu \mathrm{mol} \mathrm{m} \mathrm{m}^{-2} \mathrm{~s}^{-1}\right.$ or $\left.\left.86 \mu \mathrm{mol} \mathrm{m} \mathrm{m}^{-2} \mathrm{~s}^{-1}\right)\right]$ and two sealing systems (natural and conventional ventilation), with six replicates of one vial each. The plant height, diameter of the largest pseudobulb, length of the largest root and of the largest leaf, fresh weight and number of leaves, roots and shoots were evaluated. The use of both the banana pulp and peel as additives in the culture medium formulation promoted the C. nobilior growth. The natural ventilation system increased the plant height, pseudobulb diameter and leaf length, while the conventional system promoted tillering.

KEYWORDS: Orchidaceae, ornamental horticulture, micropropagation, native plant, Brazilian Savanna.

\section{INTRODUCTION}

The Orchidaceae family stands out in the sector of ornamental flowers and plants due to its genetic combinations, the beauty of its flowers, and its food and pharmacological potential (Silva et al. 2017, Zahara et al. 2017). This family has a share in the world market, moving tens of billions of dollars annually (Suzuki 2014). This representativeness is mainly due to new hybrids resulting from crosses that producers add to the market annually $(2,345$ cultivars are registered) (Junqueira \& Peetz 2017).

\section{RESUMO}

Crescimento in vitro de Cattleya nobilior Rchb. f.: meios de cultura, sistemas de vedação e irradiância

Alguns fatores podem influenciar no cultivo in vitro de orquídeas nativas, destacando-se o meio de cultura, o sistema de vedação dos frascos e a luz. Objetivou-se avaliar a adição de polpa e casca de banana na formulação dos meios de cultura, sistema de vedação e irradiância, no crescimento in vitro de Cattleya nobilior Rchb. f. Foi utilizado delineamento inteiramente casualizado, em esquema fatorial com cinco meios de cultura [Murashige \& Skoog suplementado ou não com polpa ou casca de banana $\left.\left(100 \mathrm{ou} 200 \mathrm{~g} \mathrm{~L}^{-1}\right)\right]$, duas condições de luz [lâmpadas LED $3.000 \mathrm{~K}\left(43 \mu \mathrm{mol} \mathrm{m}{ }^{-2} \mathrm{~s}^{-1}\right.$ ou $86 \mu \mathrm{mol} \mathrm{m} \mathrm{m}^{-2} \mathrm{~s}^{-1}$ )] e dois sistemas de vedação (ventilação natural e convencional), com seis repetições de um frasco cada. Foram avaliados a altura da planta, diâmetro do maior pseudobulbo, comprimento da maior raiz e da maior folha, massa fresca e número de folhas, raízes e brotos. Tanto a utilização de polpa quanto de casca de banana como aditivos na formulação dos meios de cultura promoveram o crescimento de C. nobilior. O sistema de ventilação natural promoveu incremento na altura de planta, diâmetro de pseudobulbo e comprimento de folha, enquanto o sistema convencional promoveu perfilhamento.

PALAVRAS-CHAVE: Orchidaceae, horticultura ornamental, micropropagação, planta nativa, Cerrado.

The Cattleya genus is among the most commercialized in Brazil, competing with other orchids such as Phalaenopsis and Dendrobium. This genus has about 48 species, distributed throughout the tropical America, a region characterized by bright habitats, with high relative humidity. Its flowers are large and have countless colors (Faria et al. 2010, Cardoso 2014, Junqueira \& Peetz 2017). An important species of this genus is Cattleya nobilior Rchb. f., present in the Brazilian Savanna and Amazon biomes.

The seminiferous propagation of orchids in nature is unfeasible, because only $2-3 \%$ of these

\footnotetext{
${ }^{1}$ Received: Dec. 17, 2020. Accepted: Feb. 17, 2021. Published: Mar. 30, 2021. DOI: 10.1590/1983-40632021v5167131.

${ }^{2}$ Universidade Federal da Grande Dourados, Faculdade de Ciências Agrárias, Dourados, MS, Brasil.

E-mail/ORCID: kalianadefreitas@gmail.com/0000-0003-2223-3676; josesorgato@ufgd.edu.br/0000-0003-0001-5467; jacke.schultz@gmail.com/0000-0001-9497-2975; luanmarlon@hotmail.com/0000-0002-7278-7696.
} 
seeds germinate. A symbiotic association with mycorrhizal fungi is necessary for germination to occur, as these seeds do not have sufficient nutrient reserves (Faria et al. 2012, Yeung et al. 2018). Therefore, in vitro culture is an alternative for both the commercial propagation and conservation of species, especially C. nobilior (Faria et al. 2012, Cardoso 2014, Silva et al. 2017).

Several factors may influence the germination, growth and development of plants grown in vitro. These factors include the culture medium, sealing system and light condition used for cultivation (Silva et al. 2015, Silva et al. 2016, Sorgato et al. 2020). Some adjustments are still necessary in the culture medium formulation for each orchid species, especially native ones. Some authors report that banana acts as a vitamin supplement and potassium source, and stimulates growth and rooting in in vitro propagation (George et al. 2008, Ferreira et al. 2010, Su et al. 2012, Dolce et al. 2020). However, this supplement is still little studied in the in vitro culture of orchid species from the Brazilian Savanna.

The microenvironment inside culture vials may vary, depending on the sealing system used. Crops using natural ventilation provide gaseous exchanges between the inside of the vial and the atmospheric air, influencing the in vitro plant growth (Calvete et al. 2002, Silva et al. 2016). Light also acts on various metabolic processes in plants. Thereby, some authors have used light conditions in their studies as a way to optimize the propagation in growth rooms (Silva et al. 2015).

Supplementing the culture medium with banana pulp or peel, using a sealing system that allows gas exchange, and providing irradiance with 3,000 K LED lamps may positively influence the in vitro culture of the Brazilian Savanna orchid species C. nobilior. Thus, this study aimed to evaluate the addition of banana pulp and peel, as a function of culture medium, sealing system and irradiance, in the in vitro growth of Cattleya nobilior Rchb. $\mathrm{f}$.

\section{MATERIAL AND METHODS}

The plant material included seeds from mature fruits of Cattleya nobilior Rchb. f., which came from natural pollination matrices of the private reserve of natural heritage Buraco das Araras, in Jardim, Mato Grosso do Sul State, Brazil, in 2017.
The seeds were taken to the laboratory, evaluated for viability by the tetrazolium test, and then placed in a silica gel desiccator $\left(25 \pm 2{ }^{\circ} \mathrm{C} ; 75 \%\right.$ $\mathrm{RH})$ for 14 days. After this period, they were removed from the desiccator, and a homogeneous sample was subjected again to the tetrazolium test. After viability confirmation, a sample of $0.005 \mathrm{~g}$ of seeds was taken to an aseptic environment and disinfected with $15 \mathrm{~mL}$ of a $0.8 \%$ sodium hypochlorite solution, remaining immersed for $5 \mathrm{~min}$. The seed suspension was then diluted to $50 \mathrm{~mL}$ and washed three times with sterile distilled water. Subsequently, the suspension volume was completed to $50 \mathrm{~mL}$ with sterile autoclaved distilled water $\left(121^{\circ} \mathrm{C}\right.$ and $1.1 \mathrm{~atm}$ pressure for $20 \mathrm{~min}$ ), for in vitro sowing, by inoculating $1,000 \mu \mathrm{L}$ of the seed suspension per culture vial.

A total of $60 \mathrm{~mL}$ of the Murashige \& Skoog (1962) culture medium was used at half the normal salt concentration $(1 / 2 \mathrm{MS})$, in a $600 \mathrm{~mL}$ vial. Subsequently, the vials with the inoculated seeds were placed in a growth room with controlled temperature and photoperiod $\left(25 \pm 2{ }^{\circ} \mathrm{C} ; 16 \mathrm{~h} / 8 \mathrm{~h}\right)$, and $22 \mu \mathrm{mol} \mathrm{m} \mathrm{m}^{-2} \mathrm{~s}^{-1}$ of irradiance were provided by two white fluorescent lamps.

After 210 days of culture, the plants were standardized for size $(1.0 \pm 0.3 \mathrm{~cm})$ and subcultured for the beginning of the experimental period. For seedling growth, Murashige \& Skoog (1962) was used as a culture medium, supplemented with $30 \mathrm{~g} \mathrm{~L}^{-1}$ of sucrose and gelled with $7.0 \mathrm{~g} \mathrm{~L}^{-1}$ of bacteriological agar (Himedia ${ }^{\mathrm{TM}}$, India). This medium was used both as a control and supplemented with $100 \mathrm{~g} \mathrm{~L}^{-1}$ of banana pulp (B100), $200 \mathrm{~g} \mathrm{~L}^{-1}$ of banana pulp (B200), $100 \mathrm{~g} \mathrm{~L}^{-1}$ of banana peel (C100) and $200 \mathrm{~g} \mathrm{~L}^{-1}$ of banana peel (C200). Senescent banana (Musa spp. cv. Nanica) fruits were used to supplement the culture media. Subsequently, the $\mathrm{pH}$ of the medium was measured and adjusted to 5.8, using $0.1 \mathrm{M} \mathrm{KOH}$ prior to autoclaving $\left(121{ }^{\circ} \mathrm{C}\right.$ and $1.1 \mathrm{~atm}$ pressure), for $20 \mathrm{~min}$. Then, $30 \mathrm{~mL}$ of the medium were distributed in $250 \mathrm{~mL}$ vials. After the media reached room temperature, the vials were transferred to a sterile environment.

Three plants were inoculated per culture vial. The vials containing each culture medium were then divided into two sets and subjected to two sealing systems: half of the vials were hermetically sealed with polyvinyl chloride (PVC) film (conventional ventilation system - CVS) and the other half with PVC film perforated and covered with cotton filter 
(natural ventilation system - NVS), thus allowing gas exchange. Then, the cultures were allocated under two different irradiances: $43 \mu \mathrm{mol} \mathrm{m} \mathrm{m}^{-2} \mathrm{~s}^{-1}$ (3,000 K-1 LED) or $86 \mu \mathrm{mol} \mathrm{m}^{-2} \mathrm{~s}^{-1}$ (3,000 K-2 LED), in an environment with controlled temperature and photoperiod $\left(25 \pm 2^{\circ} \mathrm{C} ; 16 \mathrm{~h}\right)$, each set being exposed to one light condition.

After 90 days of subculture, the plants were removed from the vials and washed under running water until the culture medium was completely removed. The following were evaluated: plant height, diameter of the largest pseudobulb ( $\mathrm{mm}$ ), length of the largest root $(\mathrm{mm})$, length of the largest leaf $(\mathrm{mm})$, fresh weight $(\mathrm{g})$ and number of leaves, roots and shoots. A digital caliper was used to determine the plant height, diameter of the largest pseudobulb, length of the largest root and length of the largest leaf, while an analytical scale was used to determine the fresh weight. After the evaluations, the treatments were photographed with a camera attached to a mini photographic studio.

The experimental design was completely randomized and the treatments were arranged in a $5 \mathrm{x}$ $2 \times 2$ factorial scheme (five culture media, two sealing systems and two light conditions), with six replicates of one vial each. The results were submitted to analysis of variance and compared by the Tukey test $(p<0.05)$, with the Sisvar software (Statistical Analysis Program v. 5.3; Universidade Federal de Lavras, MG).

\section{RESULTS AND DISCUSSION}

All the analyzed characteristics were significant both together and in isolation. The triple interaction culture medium $\mathrm{x}$ sealing system $\mathrm{x}$ irradiance was significant for the variables plant height, diameter of the largest pseudobulb, length of the largest root, length of the largest leaf and fresh weight. The interaction culture medium $\mathrm{x}$ irradiance was significant for number of leaves and number of roots. The factor sealing system alone influenced the number of leaves and number of pseudobulbs $(\mathrm{p}<0.05)$ (Table 1).

The use of the culture medium B100+ NVS + 3,000 K-2 LED provided the highest average plant height $(38.79 \mathrm{~mm})$. However, the use of B100+ $\mathrm{NVS}+3,000 \mathrm{~K}-1(32.54 \mathrm{~mm}), \mathrm{B} 200+\mathrm{NVS}+$ $3,000 \mathrm{~K}-2(27.30 \mathrm{~mm})$ and C200 + NVS + 3,000 K-2 $(30.47 \mathrm{~mm})$ had no significant effect. A significant difference, in relation to the first treatment, occurred only for plants grown in the same culture medium and at the same irradiance, but under the conventional system (14.16 mm) (Table 2).

In agreement with the results found in the present study, Araújo et al. (2006) observed that, when grown in a Knudson medium supplemented with $100 \mathrm{~g} \mathrm{~L}^{-1}$ of banana pulp, Cattleya loddgesii 'Grande' x Cattleya loddgesii 'Alba' seedlings also showed a higher height. The authors reported that this result may be related to the fact that bananas promote shoot development and stimulate the emission of adventitious shoots in in vitro culture of orchids.

The natural ventilation system also influenced the height of C. nobilior plants. Silva et al. (2014) and Silva et al. (2016) reported that sealing systems that allow gas exchange (between the inside of the vial and the atmospheric air) favor the plant growth, in

Table 1. Summary of the analysis of variance for plant height (PH), diameter of the largest pseudobulb (PD), length of the largest root (RL), length of the largest leaf (LL), fresh weight (FW), number of leaves (NL), roots (NR) and shoots (NS) of Cattleya nobilior Rchb. plants.

\begin{tabular}{|c|c|c|c|c|c|c|c|c|c|}
\hline \multirow{3}{*}{$\mathrm{VF}$} & \multirow{3}{*}{ DF } & \multicolumn{8}{|c|}{ - Mean square } \\
\hline & & $\mathrm{PH}$ & PD & RL & LL & FW & NL & NR & NS \\
\hline & & & & $\mathrm{mm}-$ & & $\mathrm{g}$ & $1 \mathrm{NL}$ & 1 IV & IVI \\
\hline I & 1 & $31.05^{\mathrm{ns}}$ & $0.03^{\text {ns }}$ & $0.70^{\mathrm{ns}}$ & $389.62 *$ & $0.05^{\mathrm{ns}}$ & $50.12^{*}$ & $50.12^{\mathrm{ns}}$ & $3.48^{*}$ \\
\hline $\mathrm{CM}$ & 4 & $319.88^{*}$ & $1.37^{\mathrm{ns}}$ & $99.51^{*}$ & $103.00^{\mathrm{ns}}$ & $0.99 *$ & $63.20^{\mathrm{ns}}$ & $63.20^{\mathrm{ns}}$ & $1.70^{\mathrm{ns}}$ \\
\hline SS & 1 & $1,190.32 *$ & $3.49^{*}$ & $33.20^{\mathrm{ns}}$ & $1,882.82 *$ & $0.55^{\mathrm{ns}}$ & $135.57^{*}$ & $135.57 *$ & $10.53^{*}$ \\
\hline I x CM & 4 & 198.05* & $3.76^{*}$ & $82.53^{*}$ & $72.02^{\mathrm{ns}}$ & $1.84^{*}$ & $163.80 *$ & $163.80 *$ & $0.52^{\mathrm{ns}}$ \\
\hline Ix SS & 1 & $19.97^{\mathrm{ns}}$ & $4.45^{*}$ & $0.99^{\text {ns }}$ & $68.90^{\mathrm{ns}}$ & $1.44 *$ & $16.46^{\mathrm{ns}}$ & $16.46^{\mathrm{ns}}$ & $0.10^{\text {ns }}$ \\
\hline $\mathrm{CM} \times \mathrm{SS}$ & 4 & $307.57 *$ & $2.52 *$ & $36.60^{\text {ns }}$ & $133.40^{\mathrm{ns}}$ & $1.18^{*}$ & $20.86^{\text {ns }}$ & $20.86^{\mathrm{ns}}$ & $1.57^{\mathrm{ns}}$ \\
\hline I x CM x SS & 4 & $293.36^{*}$ & $2.74 *$ & $21.39 *$ & $313.05 *$ & $1.16^{*}$ & $17.88^{\mathrm{ns}}$ & $17.88^{\mathrm{ns}}$ & $1.20^{\text {ns }}$ \\
\hline Total & & $12,511.58$ & 114.74 & $37,683.91$ & $11,218.50$ & 52.32 & $4,045.76$ & $2,598.55$ & 153.87 \\
\hline $\mathrm{OM}$ & & 24.02 & 2.37 & 42.18 & 18.16 & 0.92 & 8.65 & 9.17 & 2.14 \\
\hline CV (\%) & & 16.04 & 12.91 & 17.48 & 19.25 & 16.42 & 25.60 & 20.17 & 20.20 \\
\hline
\end{tabular}

* Significant; ${ }^{\text {ns }}$ not significant by the Tukey test at $5 \%$ of probability. VF: variation factor; DF: degrees of freedom; OM: overall mean; CM: culture medium; SS: sealing system; I: irradiance. 
Table 2. Height of Cattleya nobilior Rchb. f. plants depending on the culture medium, sealing system and irradiance.

\begin{tabular}{|c|c|c|c|c|}
\hline \multicolumn{5}{|c|}{ Plant height } \\
\hline \multirow{2}{*}{ Medium } & \multicolumn{2}{|c|}{ Natural ventilation } & \multicolumn{2}{|c|}{ Conventional ventilation } \\
\hline & 3,000 K-1 LED & $3,000 \mathrm{~K}-2 \mathrm{LED}$ & 3,000 K-1 LED & 3,000 K-2 LED \\
\hline B100 & $32.54 \mathrm{abA}^{\mathrm{a} *}$ & $38.79 \mathrm{aA}^{\mathrm{a}}$ & $20.27 \mathrm{aA}^{\mathrm{b}}$ & $14.16 \mathrm{bA}^{\mathrm{b}}$ \\
\hline B200 & $30.61 \mathrm{abA}^{\mathrm{a}}$ & $27.30 \mathrm{abcA}^{\mathrm{a}}$ & $23.04 \mathrm{aB}^{\mathrm{a}}$ & $33.02 \mathrm{aA}^{\mathrm{a}}$ \\
\hline $\mathrm{C} 100$ & $34.57 \mathrm{aA}^{\mathrm{a}}$ & $16.51 \mathrm{cB}^{\mathrm{a}}$ & $22.50 \mathrm{aA}^{\mathrm{b}}$ & $18.40 \mathrm{bA}^{\mathrm{a}}$ \\
\hline $\mathrm{C} 200$ & $21.93 \mathrm{abA}^{\mathrm{a}}$ & $30.47 \mathrm{abA}^{\mathrm{a}}$ & $23.29 \mathrm{aA}^{\mathrm{a}}$ & $17.29 \mathrm{bA}^{\mathrm{b}}$ \\
\hline MS & $20.80 \mathrm{bA}^{\mathrm{a}}$ & $18.20 \mathrm{bcA}^{\mathrm{a}}$ & $15.77 \mathrm{aA}^{\mathrm{a}}$ & $21.00 \mathrm{abA}^{\mathrm{a}}$ \\
\hline Mean & 28.09 & 26.21 & 20.97 & 20.77 \\
\hline CV (\%) & 16.04 & & & \\
\hline
\end{tabular}

comparison to airtight environments. When studying the growth of Cattleya walkeriana in different sealing systems, Moreira et al. (2013) observed a higher plant height when using ventilation systems, in comparison to conventional sealing.

Furthermore, the light condition provided to the propagated material is important for the regulation of various biochemical pathways that control from growth to morphogenesis. Importantly, plant responses to light irradiance strongly correlate with the cultivated plant species (Hung et al. 2016, Taiz et al. 2017).

The highest values for diameter of the largest pseudobulb occurred for the culture medium $\mathrm{C} 200+\mathrm{NVS}+3,000 \mathrm{~K}-2$ (3.41 mm), not differing significantly from the results for other culture media under the same irradiance and sealing system. Thus, under these conditions, the sealing system and irradiance influenced the pseudobulb diameter more than the culture medium (Table 3 ).
The use of vials with the natural ventilation system together with 3,000 K-2 LED increased the diameter of $C$. nobilior pseudobulbs, which averaged $2.75(\mathrm{~mm})$. The hermetic sealing of vials can increase both the $\mathrm{CO}_{2}$ and ethylene gas, what may lead to physiological changes in the plants (Silva et al. 2014, Silva et al. 2017). Therefore, the gas exchange provided by the natural ventilation system allows the elimination of ethylene to the external environment, and thus contributes to the increase in the pseudobulb diameter (Ribeiro et al. 2019).

Photon flux density, light quality and photoperiod directly influence the morphogenesis of plants grown in vitro (Lian et al. 2002, Silva et al. 2015, Taiz et al. 2017). Providing low irradiance to plants leads to poor photosynthesis, causing symptoms such as etiolation. On the other hand, a high irradiance can generate oxygen radicals, causing photoinhibition (Araújo et al. 2009). The results for diameter of the largest pseudobulb suggest that the

Table 3. Diameter of Cattleya nobilior Rchb. f. pseudobulbs depending on the culture medium, sealing system and irradiance.

\begin{tabular}{|c|c|c|c|c|}
\hline \multicolumn{5}{|c|}{ Pseudobulb diameter } \\
\hline \multirow{2}{*}{ Medium } & \multicolumn{2}{|c|}{ Natural ventilation } & \multicolumn{2}{|c|}{ Conventional ventilation } \\
\hline & 3,000 K-1 LED & 3,000 K-2 LED & 3,000 K-1 LED & 3,000 K-2 LED \\
\hline B100 & $2.83 \mathrm{aA}^{\mathrm{a} *}$ & $2.76 \mathrm{aA}^{\mathrm{a}}$ & $2.20 \mathrm{aA}^{\mathrm{a}}$ & $0.56 \mathrm{cB}^{\mathrm{b}}$ \\
\hline B200 & $2.12 \mathrm{aB}^{\mathrm{a}}$ & $3.14 \mathrm{aA}^{\mathrm{a}}$ & $1.95 \mathrm{aB}^{\mathrm{a}}$ & $2.93 \mathrm{bcA}^{\mathrm{a}}$ \\
\hline $\mathrm{C} 100$ & $2.56 \mathrm{aA}^{\mathrm{a}}$ & $2.20 \mathrm{aA}^{\mathrm{a}}$ & $2.54 \mathrm{aA}^{\mathrm{a}}$ & $1.60 \mathrm{abB}^{\mathrm{a}}$ \\
\hline $\mathrm{C} 200$ & $2.08 \mathrm{aB}^{\mathrm{b}}$ & $3.41 \mathrm{aA}^{\mathrm{a}}$ & $3.24 \mathrm{aA}^{\mathrm{a}}$ & $2.01 \mathrm{aB}^{\mathrm{b}}$ \\
\hline MS & $2.11 \mathrm{aA}^{\mathrm{a}}$ & $2.25 \mathrm{aA}^{\mathrm{a}}$ & $1.99 \mathrm{aB}^{\mathrm{a}}$ & $3.06 \mathrm{aA}^{\mathrm{a}}$ \\
\hline Mean & 2.34 & 2.75 & 2.38 & 2.03 \\
\hline $\mathrm{CV}(\%)$ & 12.91 & & & \\
\hline
\end{tabular}


3,000 K-2 LED irradiance in conjunction with gas exchange seal was appropriate. This combination increased the pseudobulb diameter probably due to the greater accumulation of photoassimilates, since pseudobulbs act as a storage organ.

The B200 medium, combined with the conventional ventilation system and $3,000 \mathrm{~K}-2$, provided the highest increase in length of the largest root $(14.50 \mathrm{~mm})$, not differing from the B100, C100 and Murashige \& Skoog (1962) media under the same irradiance and sealing system. There was no significant difference in this variable for the treatment using the same irradiance in the B200 medium under conventional sealing system, nor for the treatment using the same medium and irradiance under the sealing system with gas exchanges (Table 4). Vieira et al. (2009) observed that the medium containing banana pulp + coconut water showed a better root development for a Cattleya hybrid. Gonçalves et al.
(2016) used this organic supplement in the in vitro culture of the intergeneric hybrid Laeliocattleya and observed that the addition of banana pulp to the culture medium improved the root system.

In the present study, the supplementation with banana pulp improved the root system quality. This fruit can stimulate rooting, due to its amount of potassium and mineral salts, its pulp being also a rich source of cytokinins, auxins and gibberellins (Khalifah 1966, Lahav \& Gottreich 1984, Arditti and Ernst 1993, Dolce et al. 2020).

The highest values of leaf length occurred for C100 + NVS + 3,000 K-1 (29.63 mm). These values did not differ significantly from those of the other culture media under the same sealing system and irradiance, but were higher than those of $\mathrm{C} 100+$ $\mathrm{NVS}+3,000 \mathrm{~K}-2(12.12 \mathrm{~mm})$ and $\mathrm{C} 100+\mathrm{CVS}+$ 3,000 K-1 (14.84 mm) (Table 5). The results may be due to the use of the sealing system allowing

Table 4. Length of the largest root of Cattleya nobilior Rchb. f., depending on the culture medium, sealing system and irradiance.

\begin{tabular}{|c|c|c|c|c|}
\hline \multicolumn{5}{|c|}{ Length of the largest root } \\
\hline \multirow{2}{*}{ Medium } & \multicolumn{2}{|c|}{ Natural ventilation } & \multicolumn{2}{|c|}{ Conventional ventilation } \\
\hline & 3,000 K-1 LED & 3,000 K-2 LED & 3,000 K-1 LED & 3,000 K-2 LED \\
\hline B100 & $13.33 \mathrm{aA}^{\mathrm{a} *}$ & $6.16 \mathrm{bB}^{\mathrm{a}}$ & $12.33 \mathrm{aA}^{\mathrm{a}}$ & $8.50 \mathrm{abA}^{\mathrm{a}}$ \\
\hline $\mathrm{B} 200$ & $7.83 \mathrm{abcA}^{\mathrm{a}}$ & $10.00 \mathrm{abA}^{\mathrm{a}}$ & $11.66 \mathrm{aA}^{\mathrm{a}}$ & $14.50 \mathrm{aA}^{\mathrm{a}}$ \\
\hline $\mathrm{C} 100$ & $10.83 \mathrm{abA}^{\mathrm{a}}$ & $9.16 \mathrm{abA}^{\mathrm{a}}$ & $9.50 \mathrm{aA}^{\mathrm{a}}$ & $10.50 \mathrm{abA}^{\mathrm{a}}$ \\
\hline $\mathrm{C} 200$ & $4.00 \mathrm{cA}^{\mathrm{a}}$ & $4.83 \mathrm{bA}^{\mathrm{a}}$ & $8.16 \mathrm{aA}^{\mathrm{a}}$ & $6.00 \mathrm{bA}^{\mathrm{a}}$ \\
\hline MS & $6.66 \mathrm{bcB}^{\mathrm{a}}$ & $13.65 \mathrm{aA}^{\mathrm{a}}$ & $7.16 \mathrm{aA}^{\mathrm{a}}$ & $8.66 \mathrm{abA}^{\mathrm{b}}$ \\
\hline Mean & 8.53 & 8.76 & 9.76 & 9.63 \\
\hline $\mathrm{CV}(\%)$ & 17.48 & & & \\
\hline
\end{tabular}

Table 5. Length of Cattleya nobilior Rchb. f. leaves, depending on the culture medium, sealing system and irradiance.

\begin{tabular}{|c|c|c|c|c|}
\hline \multicolumn{5}{|c|}{ Leaf length } \\
\hline \multirow{2}{*}{ Medium } & \multicolumn{2}{|c|}{ Natural ventilation } & \multicolumn{2}{|c|}{ Conventional ventilation } \\
\hline & 3,000 K-1 LED & 3,000 K-2 LED & 3,000 K-1 LED & 3,000 K-2 LED \\
\hline B100 & $27.05 \mathrm{aA}^{\mathrm{a} *}$ & $24.4 \mathrm{abA}^{\mathrm{a}}$ & $11.85 \mathrm{abA}^{\mathrm{b}}$ & $7.90 \mathrm{aA}^{\mathrm{b}}$ \\
\hline B200 & $24.67 \mathrm{aA}^{\mathrm{a}}$ & $22.30 \mathrm{abcA}^{\mathrm{a}}$ & $16.42 \mathrm{abA}^{\mathrm{a}}$ & $17.50 \mathrm{aA}^{\mathrm{a}}$ \\
\hline $\mathrm{C} 100$ & $29.63 \mathrm{aA}^{\mathrm{a}}$ & $12.12 \mathrm{cB}^{\mathrm{a}}$ & $14.84 \mathrm{abA}^{\mathrm{b}}$ & $14.35 \mathrm{aA}^{\mathrm{a}}$ \\
\hline $\mathrm{C} 200$ & $21.06 \mathrm{aA}^{\mathrm{a}}$ & $26.32 \mathrm{aA}^{\mathrm{a}}$ & $22.95 \mathrm{aA}^{\mathrm{a}}$ & $9.35 \mathrm{aB}^{\mathrm{b}}$ \\
\hline MS & $20.17 \mathrm{aA}^{\mathrm{a}}$ & $12.68 \mathrm{bcA}^{\mathrm{a}}$ & $10.18 \mathrm{bA}^{\mathrm{b}}$ & $16.70 \mathrm{aA}^{\mathrm{a}}$ \\
\hline Mean & 24.51 & 19.56 & 15.25 & 13.16 \\
\hline $\mathrm{CV}(\%)$ & 19.25 & & & \\
\hline
\end{tabular}


gas exchange together with the addition of banana pulp. This system allows the gas exchange between the inside of the vial and the atmospheric air, influencing the in vitro growth of plants (Silva et al. 2016). Moreover, supplementing the culture medium with banana can increase the orchid growth in the laboratory, improving some characteristics such as leaf length (Aktar et al. 2008).

For the fresh weight of plants, there was a significant interaction between medium, sealing system and irradiance. The highest values occurred for B200+CVS + 3,000 K-2 (2.30 g), with a significant difference, in comparison to the other treatments (Table 6).

Similarly to the results of this study, Hermann et al. (2011) observed that an alternative medium added with banana pulp significantly influenced the higher fresh weight of Brassavola tuberculata seedlings, in comparison to the Murashige \& Skoog (1962) and Knudson C media.

The conventional sealing method used provided higher fresh weight values. According to Silva et al. (2014), this may be due to the higher relative humidity inside the vials, as a result of total sealing, allowing a greater water accumulation by the tissues. Furthermore, the wavelength used in the in vitro culture can also promote carbohydrate accumulation and anatomical changes (Hung et al. 2016). These factors may have directly contributed to the increase in the plant fresh weight.

For number of leaves and roots, the interaction culture medium $\mathrm{x}$ irradiance showed higher values in the combination $\mathrm{B} 100+3,000 \mathrm{~K}-1$, averaging 15.75 leaves and 12.83 roots. When studying the in vitro culture of Dendrobium sp., Islam et al. (2015) observed that the use of $100 \mathrm{~g} \mathrm{~L}^{-1}$ or $200 \mathrm{~g} \mathrm{~L}^{-1}$ of banana decreased the number of leaves, in comparison to the media without the additive (Figure 1).

Moreover, when evaluating the in vitro development of $C$. loddgesii x C. loddgesii 'Alba' seedlings, Araújo et al. (2006) observed higher values for number of roots and root length in a culture medium containing 60-100 $\mathrm{g} \mathrm{L}^{-1}$ of banana pulp. Similarly, when studying a Laelio-Cattleya hybrid, Gonçalves et al. (2016) reported that the addition of banana pulp to the culture medium increased the number of roots. This effect may be due to the composition of the banana pulp, which is rich in amino acids, vitamins and growth regulators (George et al. 2008) (Figure 1).

Regarding the effect of the sealing system alone, the highest results for number of leaves and pseudobulbs occurred in the conventional system, with 9.72 leaves and 2.43 pseudobulbs (Table 7). This fact correlates with the tillering of these plants, when cultivated in hermetically sealed vials, since this type of sealing increases the rate of ethylene gas, also leading to high $\mathrm{CO}_{2}$ concentrations. This may cause physiological changes in plants, tissue differentiation and growth, as well as organ induction and differentiation (Silva et al. 2014, Silva et al. 2017). In the present study, this sealing contributed to the formation of shoots and leaves.

According to the results, $C$. nobilior seedlings grew more with the use of the natural ventilation system, with the addition of banana pulp or peel, regardless of the 3,000 K LED lamp used. Therefore, these were favorable conditions to promote their in vitro growth (Figure 2). According to Silva et al. (2016), an explanation for this fact is that sealing

Table 6. Fresh weight of Cattleya nobilior Rchb. f., depending on the culture medium, sealing system and irradiance.

\begin{tabular}{|c|c|c|c|c|}
\hline \multicolumn{5}{|c|}{ Fresh weight } \\
\hline \multirow{2}{*}{ Medium } & \multicolumn{2}{|c|}{ Natural ventilation } & \multicolumn{2}{|c|}{ Conventional ventilation } \\
\hline & 3,000 K-1 LED & $3,000 \mathrm{~K}-2 \mathrm{LED}$ & $3,000 \mathrm{~K}-1 \mathrm{LED}$ & $3,000 \mathrm{~K}-2 \mathrm{LED}$ \\
\hline B100 & $1.66 \mathrm{aA}^{\mathrm{a} *}$ & $0.93 \mathrm{aB}^{\mathrm{a}}$ & $0.77 \mathrm{aA}^{\mathrm{b}}$ & $0.38 \mathrm{bA}^{\mathrm{a}}$ \\
\hline $\mathrm{B} 200$ & $0.95 \mathrm{abA}^{\mathrm{a}}$ & $1.02 \mathrm{aA}^{\mathrm{b}}$ & $0.70 \mathrm{aB}^{\mathrm{a}}$ & $2.30 \mathrm{aA}^{\mathrm{a}}$ \\
\hline $\mathrm{C} 100$ & $1.52 \mathrm{aA}^{\mathrm{a}}$ & $0.62 \mathrm{aB}^{\mathrm{a}}$ & $0.78 \mathrm{aA}^{\mathrm{b}}$ & $0.77 \mathrm{bA}^{\mathrm{a}}$ \\
\hline $\mathrm{C} 200$ & $0.58 \mathrm{bA}^{\mathrm{a}}$ & $0.99 \mathrm{aA}^{\mathrm{a}}$ & $0.81 \mathrm{aA}^{\mathrm{a}}$ & $0.60 \mathrm{bA}^{\mathrm{a}}$ \\
\hline Mean & 1.06 & 0.91 & 0.72 & 0.98 \\
\hline CV (\%) & 16.42 & & & \\
\hline
\end{tabular}

* Lowercase letters in the column compare the culture media for the same sealing system and irradiance, while uppercase letters in the row compare the irradiance for the same culture medium and sealing system. Overwritten letters in the row compare the sealing system for the same culture medium and irradiance (Tukey; $\mathrm{p}<0.05$ ). B100: $100 \mathrm{~g}$ of banana pulp; B200: $200 \mathrm{~g}$ of banana pulp; C100: $100 \mathrm{~g}$ of banana peel; C200: $200 \mathrm{~g}$ of banana peel; MS: Murashige \& Skoog (1962); 3,000 K-1 LED: $43 \mu \mathrm{mol} \mathrm{m} \mathrm{s}^{-2}$; $3,000 \mathrm{~K}-2$ LED: $86 \mu \mathrm{mol} \mathrm{m}^{-2} \mathrm{~s}^{-1}$. 

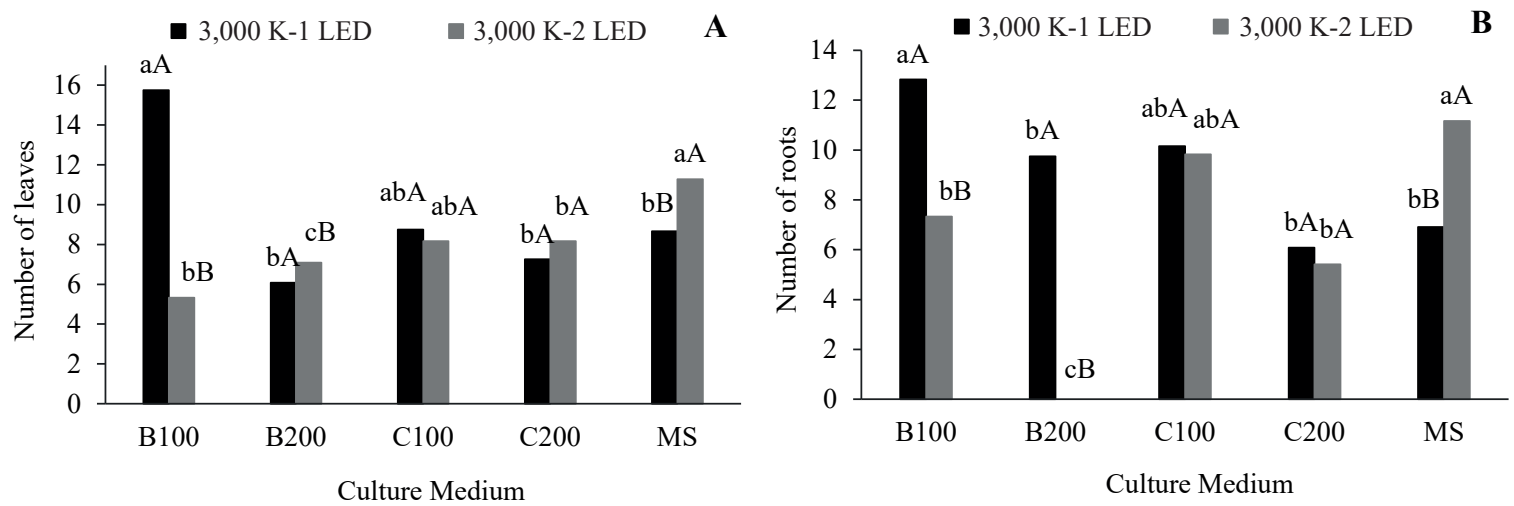

Figure 1. Number of leaves (A) and roots (B) of Cattleya nobilior Rchb. f., depending on the culture medium and irradiance. B100: $100 \mathrm{~g}$ of banana pulp; B200: $200 \mathrm{~g}$ of banana pulp; C100: $100 \mathrm{~g}$ of banana peel; C200: $200 \mathrm{~g}$ of banana peel; MS: Murashige \& Skoog (1962); 3,000 K-1 LED: $43 \mu \mathrm{mol} \mathrm{m}{ }^{-2} \mathrm{~s}^{-1}$; 3,000 K-2 LED: $86 \mu \mathrm{mol} \mathrm{m} \mathrm{m}^{-2} \mathrm{~s}^{-1}$. Lowercase letters compare the culture media at the same irradiance and uppercase letters the same culture medium at different irradiances (Tukey; $\mathrm{p}<0.05)$.

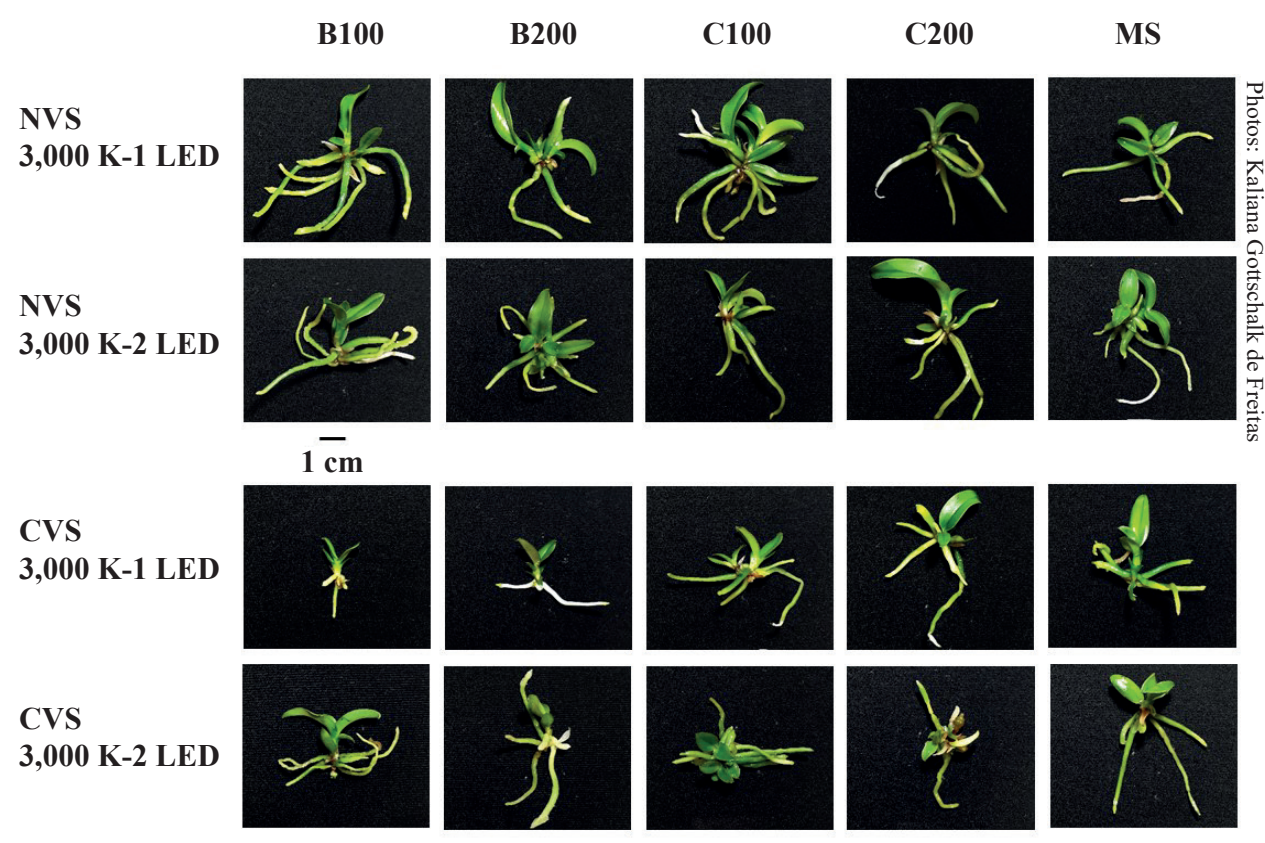

Figure 2. Cattleya nobilior Rchb. f. at 90 days after the beginning of the experimental period, as a function of the culture medium [B100: $100 \mathrm{~g}$ of banana pulp; B200: $200 \mathrm{~g}$ of banana pulp; C100: $100 \mathrm{~g}$ of banana peel; C200: $200 \mathrm{~g}$ of banana peel; MS: Murashige \& Skoog (1962)], sealing system (NVS: natural ventilation system; CVS: conventional ventilation system) and irradiance (3,000 K-1 LED: $43 \mu \mathrm{mol} \mathrm{m}{ }^{-2} \mathrm{~s}^{-1}$; 3,000 K-2 LED: $86 \mu \mathrm{mol} \mathrm{m}^{-2} \mathrm{~s}^{-1}$ ).

Table 7. Number of leaves (NL) and pseudobulbs (NP) of Cattleya nobilior Rchb. f., depending on the sealing system.

\begin{tabular}{lll}
\hline \multicolumn{1}{c}{ Sealing system } & NL & NP \\
\hline NVS & $7.59 \mathrm{~b}^{*}$ & $1.84 \mathrm{~b}$ \\
CVS & $9.72 \mathrm{a}$ & $2.43 \mathrm{a}$ \\
\hline Mean & 8.65 & 2.13 \\
\hline CV $(\%)$ & 25.60 & 20.20 \\
\hline
\end{tabular}

* Means followed by the same letter in each variable do not differ by the Tukey test $(\mathrm{p}<0.05)$. NVS $=$ natural ventilation system; CVS $=$ conventional ventilation system. systems that allow gas exchange between the microenvironment inside the vial and the atmospheric air decrease the accumulation of ethylene gas and $\mathrm{CO}_{2}$, favoring the plant growth in in vitro culture.

\section{CONCLUSIONS}

1. The use of banana pulp and peel as additives in the culture medium formulation promotes the in vitro growth of Cattleya nobilior Rchb. f.; 
2. The natural ventilation system increases the height, diameter and length of $C$. nobilior, while the conventional system promotes tillering.

\section{REFERENCES}

AKTAR, S.; NASIRUDDIN, K. M.; HOSSAIN, K. Effects of different media and organic additives interaction on in vitro regeneration of Dendrobium orchid. Journal of Agriculture \& Rural Development, v. 6, n. 1, p. 69-74, 2008.

ARAÚJO, A. G.; PASQUAL, M.; PEREIRA, A. R.; ROCHA, H. S. Crescimento in vitro de Laelia tenebrosa (Orquidaceae) em diferentes concentrações de sais de Knudson C e carvão ativado. Plant Cell Culture \& Micropropagation, v. 2, n. 2, p. 53-106, 2006.

ARAÚJO, S. A. C.; DEMINICIS, B. B. Fotoinibição da fotossíntese. Revista Brasileira de Biociências, v. 7, n. 4, p. 463-472, 2009.

ARDITTI, J.; ERNST, R. Micropropagation of orchids. New York: Wiley, 1993.

CALVETE, E. O.; AZEVEDO, M.; BORDIGNON, M. H.; SUZIN, M. Análises anatômicas e da biomassa em plantas de morangueiro cultivadas in vitro e ex vitro. Horticultura Brasileira, v. 20, n. 4, p. 649-653, 2002.

CARDOSO, J. C. Publicação em cultivo in vitro de plantas: qualidade para o avanço científico e tecnológico. Horticultura Brasileira, v. 32, n. 4, p. 383-384, 2014.

DOLCE, N. R.; MEDINA, R. D.; TERADA, G.; GONZÁLEZ-ARNAO, M. T.; FLACHSLAND, E. A. In vitro propagation and germplasm conservation of wild orchids from South America. In: KHASIM, S.; HEGDE, S.; GONZÁLEZ-ARNAO, M.; THAMMASIRI, K. (ed.). Orchid biology: recent trends \& challenges. Singapore: Springer, 2020. p. 37-94.

FARIA, R. T.; ASSIS, A. M.; CARVALHO, J. F. R. P. Cultivo de orquídeas. Londrina: Mecenas, 2010.

FARIA, R. T.; ASSIS, A. M.; UNEMOTO, L. K.; CARVAlHO, J. F. R. P. Produção de orquídeas em laboratório. Londrina: Mecenas, 2012.

FERREIRA, A. W. C.; LIMA, M. I. S.; FARIA, R. T. D.; RIBEIRO, J. P. N.; CASALI, C. A. Propagação in vitro de Baptistonia pubes (Lindl.) Chiron \& VP Castro (Oncidium pubes Lindl.) (Orchidaceae). Acta Botanica Brasilica, v. 24, n. 3, p. 636-639, 2010.

GEORGE, E. F.; HALL, M. A.; KLERK, G. Plant propagation by tissue culture. Basingstoke: Springer, 2008.

GONÇALVES, L. M.; MACHADO, P. S.; FÁTIMA, M.; BALLESTA, P.; MORA, F.; MILANEZE GUTIERRE,
M. A.; MANGOLIN, C. A. Suplementos orgánicos para el cultivo in vitro del híbrido Laeliocattleya (Orchidaceae). Idesia (Arica), v. 34, n. 1, p. 47-54, 2016.

HERRMAN, M. H.; FREITAS, E. M.; PÉRICO, E. Cultivo in vitro de plântulas de orquídea em meio de cultura alternativo. Revista Brasileira de Agrociência, v. 17, n. 1, p. 162-166, 2011.

HUNG, C. D.; HONG, C. H.; KIM, S. K.; LEE, K. H.; PARK, J. Y.; NAM, M. W.; CHOI, D. H.; LEE, H. I. LED light for in vitro and ex vitro efficient growth of economically important highbush blueberry (Vaccinium corymbosum L.). Acta Physiologiae Plantarum, v. 38, n. 152, p. 152-160, 2016.

ISLAM, M. O.; ISLAM, M. S.; SALEH, A. Effect of banana extract on growth and development of protocorm like bodies in Dendrobium sp. orchid. The Agriculturists, v. 13, n. 1, p. 101-108, 2015.

JUNQUEIRA, A. H.; PEETZ, M. Intellectual property rights in Brazilian floriculture: innovations for the growth and development of the market. Revista Brasileira de Horticultura Ornamental, v. 23, n. 3, p. 296-306, 2017.

KHALIFAH, R. A. Gibberellin-like substances from the developing banana fruit. Plant Physiology, v. 41, n. 5, p. 771-773, 1966.

LAHAV, E.; GOTTREICH, M. The effect of growth hormones on bananas: a review. Plant Growth Regulation, v. 2, n. 1, p. 15-30, 1984.

LIAN, M.; MURTHY, H. N.; PAEK, K. Effects of light emitting diodes (LEDs) on the in vitro induction and growth of bulblets of Lilium oriental hybrid 'Pesaro'. Scientia Horticulturae, v. 94, n. 1, p. 365-370, 2002.

MOREIRA, A. L.; SILVA, A. B.; SANTOS, A.; REIS, C. O.; LANDGRAF, P. R. C. Cattleya walkeriana growth in different micropropagation systems. Revista Ciência Rural, v. 43, n. 10, p. 1804-1810, 2013.

MURASHIGE, T.; SKOOG, F. A. A revised medium for rapid growth and bioassays with tobacco tissue culture. Physiology Plantarum, v. 15, n. 1, p. 473-497, 1962.

RIBEIRO, L. M.; SORGATO, J. C.; SCALON, S. D. P. Q.; SOARES, J. S.; RIBEIRO, I. S. Influência da luz, ventilação natural e tamanho do frasco no crescimento e desenvolvimento de denphal (Orchidaceae). Revista Brasileira de Ciências Agrárias, v. 14, n. 3, e5957, 2019.

SILVA, A. B.; LIMA, P. P.; OLIVEIRA, L. E. S.; MOREIRA, A. L. In vitro growth and leaf anatomy of Cattleya walkeriana (Gardner, 1839) grown in natural ventilation system. Revista Ceres, v. 61, n. 6, p. 883-890, 2014. 
SILVA, A. B.; REIS, C. O.; CAZETTA, J. O.; CARLIN, S. D.; LANDGRAF, P. R. C.; REIS, M. C. Effects of exogenous proline and a natural ventilation system on the in vitro growth of orchids. Bioscience Journal, v. 32, n. 3 , p. 619-626, 2016.

SILVA, J. A. T. da; HOSSAIN, M. M.; SHARMA, M.; DOBRÁNSZKI, J.; CARDOSO, J. C.; SONGJUN, Z. Acclimatization of in vitro-derived Dendrobium. Horticultural Plant Journal, v. 3, n. 3, p. 110-124, 2017.

SILVA, J. A. T. da; TSAVKELOVA, E. A.; NG, T. B.; PARTHIBHAN, S.; DOBRÁNSZKI, J.; CARDOSO, J. C.; RAO, M. V.; ZENG, S. Asymbiotic in vitro seed propagation of Dendrobium. Plant Cell Reports, v. 34, n. 1, p. 1685-1706, 2015.

SORGATO, J. C.; SOARES, J. S.; DAMIANI, C. R.; RIBEIRO, L. M. Effects of light, agar, activated charcoal, and culture medium on the germination and early development of Dendrobium seedlings. Australian Journal of Crop Science, v. 14, n. 4, p. 557-564, 2020.

SU, M. J.; SCHINITZER, J. A.; FARIA, R. T. Polpa de banana e fertilizantes comerciais no cultivo in vitro de orquídea. Científica, v. 40, n. 1, p. 28-34, 2012.
SUZUKI, R. M. Breve análise sobre o comércio exterior de orquídeas no Brasil. In: REUNIÃO ANUAL DO INSTITUTO DE BOTÂNICA, 21., 2014, São Paulo. Anais... São Paulo: Instituto de Botânica, 2014. p. 1-4.

TAIZ, L.; ZEIGER, E.; MOLLER, I. M.; MURPHY, A. Fisiologia vegetal. 6. ed. Porto Alegre: Artmed, 2017.

VIEIRA, J. G. Z.; UNEMOTO, L. K.; YAMAKAMI, J. K.; NAGASHIMA, G. T.; FARIA, R. T.; AGUIAR, R. $\mathrm{S}$. Propagação in vitro e aclimatização de um híbrido de Cattleya Lindl. (Orchidaceae) utilizando polpa de banana e água de coco. Cientifica, v. 37, n. 1, p. 48-52, 2009.

YEUNG, E. C.; PARK, J.; HARRY, I. S. Orchid seed germination and micropropagation: I. Background information and related protocols. In: LEE, Y.; YEUNG, E. C. (org.). Orchid propagation: from laboratories to greenhouses: methods and protocols. Singapore: Humana Press, 2018. p. 101-125.

ZAHARA, M.; DATTA, A.; BOONKORKAEN, P.; MISHRA, A. The effects of different media, sucrose concentrations and natural additives on plantlet growth of Phalaenopsis hybrid 'Pink'. Brazilian Archives of Biology and Technology, v. 60, e160149, 2017. 